\title{
Inspiration of the Unity of Morality and Profit Based on "Love" to the Development of Contemporary Society
}

\author{
Yujie Gao ${ }^{1, *}$ \\ ${ }^{1}$ School of China Metrology University of Humanities\&Foreign Languages, Hangzhou, Zhejiang 310018, China
${ }^{*}$ Corresponding author. Email: gaoyujiegyj@ 126.com
}

\begin{abstract}
ABETRACT
The relationship between morality and profit has always been the focus of everyone's thinking throughout the ages. Compared with moralism or utilitarianism, the "unity of morality and profit", which is based on love, attaches importance to the principles of humanitarianism, benevolence, and aims at balancing personal interests with the pursuit of public interests, is more in line with the development of contemporary society. Such a unified view of morality and profit is reflected in the traditional Chinese morality and profit, and at the same time, it can overcome the negative influence of utilitarianism on contemporary society to a certain extent, and is a view of morality and profit that should be promoted.
\end{abstract}

Keywords: The Debate of morality and Profit, Unity of morality and profit, Moralism, Utilitarianism.

\section{INTRODUCTION}

The concept of morality and profit involves the morality and values of a society, which refers to people's views and judgments on the relationship between morality and profit. Among them, "morality" mainly refers to the judgment standard of behavior or thought, while "profit" can be analyzed from both individual and social aspects. Since ancient times, the concept of morality and profit, that is, the debate between morality and profit, has been the focus of discussion among aspiring scholars [1-2]. This discussion has continued until modern China, and the study of the debate of morality and profit is also useful for the development of contemporary society. The purpose of this paper is to analyze the tendency of unifying morality and profit in the traditional Chinese concept of morality and profit, to show that the unified concept of morality and profit based on love is the inheritance and development of the traditional Chinese concept of morality and profit, and to clarify the inspiration and significance of this concept of morality and profit for the development of contemporary society.

\section{TRADITIONAL CHINESE MORALITY AND PROFIT}

Our basic approach to the concept of morality and profit is to insist on the "unity of morality and profit". The "unity of morality and profit" view is common in the traditional Chinese view of morality and profit, and although most ancient thinkers would discuss it from a basic position, such as moralism or utilitarianism, the idea of "unity of morality and profit" is still implicit in their views. We would like to discuss the positions held by these great scholars who implicitly held the idea of "unity of morality and profit," and thus lay the foundation for our own interpretation of morality and profit later.

\subsection{Profit-centered, Unified Morality and Profit}

In the traditional Chinese view of morality and profit, utilitarianism does not occupy the mainstream. Utilitarians tend to advocate that "morality is also profit." The term "profit" mostly refers to the collective public interest of society [3]. If an act is in the interest of the majority of people, then it is a "righteous act" worthy of respect, i.e., a moral act. 


\subsection{1."The unity of morality and profit in "morality through profit"}

Guanzi is one of the most important thinkers of the pre-Qin Dynasty, and his view of morality and profit is generally regarded as a kind of utilitarianism. However, we believe that Guanzi's view of morality and profit includes the idea of "unity of morality and profit".

In Guanzi's book, it is said, "Morality means that each one is in his own way." For Guanzi, "morality" means to do one's own job. Each person does what is appropriate for him or her, and each person works in the direction that is appropriate for him or her. After establishing the definition of "morality", Guanzi derived the concepts of "ritual" and "reason" from it: "Ritual is the one who, because of the feelings of people and the reason of morality, is also the one who makes the rules and regulations. Therefore, ritual is also called reason. The reason is also the meaning of the clear division to ordain morality. Therefore, ritual is out of morality, morality is out of reason, and reason is out of appropriateness. "Reason" refers to the understanding of rituals and moral principles [4-5], while "morality" takes "reason" as the standard to determine the appropriate direction for each person and to develop in that direction; and "ritual" takes "morality" as the standard to determine the appropriate direction for each person. Morality" is based on "morality" and forms the norms for dealing with specific matters. Therefore, Guanzi's so-called "morality" means to do one's own job according to the rules of the Zhou rites.

With regard to "profit", Guanzi believes that what is beneficial to people is "profit", and everyone aspires to "profit". According to people's tendency to avoid harm, they can be controlled by "profit", so his attitude toward "profit" is positive. However, Guanzi thinks that "people can be killed because they hate death, and they can be disadvantaged because they like profit. Therefore, a gentleman does not rest on good, does not force on evil, quietly enjoys inaction, and goes to the wisdom and the reason." Although the "morality" of the common people is the pursuit of "profit", the "morality" of the gentleman is not moved by "profit". The "morality" of a gentleman is not moved by "profit".

From the above analysis of "morality" and "profit", Guanzi does not completely deny "morality", but he insists on "profit" to produce "morality". However, his insistence on "morality" by "profit" is completely different from the moralists [6], and "profit" is the basis of "morality". We believe that Guanzi actually unified "morality" and "profit" from the perspective of utilitarianism.

\section{2. "The Unity of Morality and Profit in "Justice for Profit"}

During the two Song dynasties, the meritocracy was inherited from the meritocratic thinking of the Qin Dynasty and followed by the Enlightenment thinking of the Ming and Qing Dynasties, which was a transitional period when the inner moral tradition of Confucianism was transformed into the modern era. Ye Shi, as a great master of meritocracy, changed the emphasis on agriculture and business, and on virtue and wealth to agriculture and business and financial management, and his thinking was very progressive. In Ye Shi's view, "profit" is the basis of "morality", and only by managing money can benevolence and morality be realized. Ye Shi distinguished between wealth management and wealth collection: wealth management and "morality" were not contradictory, for wealth management could drive the country's economy, make the people rich, and stabilize society; wealth collection was the opposite of "morality", and was "to take from the people and use it for the top. The collection of wealth is opposed to "morality" and is "taken from the people for the use of the top. Therefore, Ye Shi's view of morality and profit advocates both morality and profit and the use of king and hegemony. From this, we can know that Ye Shi also insists on the importance of public interest and intends to remove the boundary between public interest and morality, so that both sides can reach a true unity.

However, in real life, "morality" and "profit" cannot be exactly the same. Thus, Ye Shih's discussion of the relationship between morality and profit also touches on the issue of "power and change," that is, the question of how to make trade-offs when morality and profit are in conflict. According to Ye, in the case of necessity, the interests of the state should take precedence, and the "morality" should be changed by "profit". Therefore, Ye Shi also stood from the perspective of "profit" and tried to achieve a balance between morality and profit, and to unify morality and profit. He has already begun to try to expand the connotation of "morality" and "unify morality and profit" in a way that "morality" covers public interest.

\section{MORALITY AS THE CENTER, UNIFYING MORALITY AND PROFIT}

In contrast to the utilitarians, the moralists are the majority in the traditional Chinese view of morality and profit. They insist that "morality is also appropriate." That is, good behavior, the behavior that should be done, is moral behavior. Only when we consciously do moral behavior can we satisfy the interests of the group and make society harmonious and stable. 


\section{1." The Unity of Morality and Profit in "Morality over Profit"}

Mencius' so-called "morality" is closely related to the core concept of his thought, "ren," which is the way to realize "ren. It manifests itself in two ways: one is to respect one's elders; the other is to obtain only what is in accordance with one's status. Mencius said, "It is not morality to take what you do not have. To be ashamed of oneself and not to fight for what is not in accordance with one's status, that is, "the heart of shame and evil is also the end of morality. From this we can see that Mencius emphasized "morality", but did not completely abandon interests, he only limited them in terms of hierarchy. Mencius internalized this "morality" into people's hearts and became their essence and conscious moral consciousness; on the contrary, Mencius' so-called "profit", which is the opposite of "morality", refers to selfish desires. Mencius attached great importance to the contradiction between morality and profit, that is, the contradiction between inner conscience and outer personal self-interest, and he made it clear that as gentlemen, we should value morality over profit, or else we will be reduced to villainy: "Those who rise up with a rooster crowing and breed for good are the disciples of Shun; those who rise up with a rooster crowing and breed for profit are the disciples of Metatarsus. To know the difference between Shun and Metatarsal, there is no other way but between profit and goodness. This is to emphasize the absolute opposition between morality and self-interest.

In summary, Mencius advocates the importance of morality over profit, but he only denies the acquisition of benefits that are not in line with one's status. Mencius' "morality" in fact includes reasonable (ritual) "profit". Moreover, Mencius elevated the importance of morality over profit to an a priori level by saying, "Those who have the title of heaven and those who have the title of man. He said, "There are those who have the title of heaven and those who have the title of man. The title of heaven is benevolence, morality, loyalty and faithfulness, and the pleasure of goodness and untiringness. In ancient times, people cultivated their heavenly titles, and the human titles followed them. Today's people cultivate their heavenly titles to get the human titles, and when they get the human titles and abandon their heavenly titles, they are very confused and will surely die. By giving play to the inner morality of benevolence and morality, one can naturally obtain the external fame and fortune (the title of public official) in accordance with oneself without striving for it, which is to place the inner moral nature above the external moral code. It is in this way that Mencius naturally unites morality and profit (in line with morality).

\section{2. "The Unity of Morality and Profit in "Generating Profit with Morality"}

Zhu Xi continued the tradition of Mencius of emphasizing morality over profit in the concept of morality and profit. He first gave "morality" a new connotation: "morality is the appropriate of heavenly justice" and "morality is the control of the heart and the appropriate of the matter". From this it can be seen that Zhu Zi associates "morality" with the Divine Principle, but at the same time he also emphasizes the control of profit by morality. What we need to note here is that Zhu $\mathrm{Zi}$ does not completely reject "profit", he believes that it is certainly good to have "profit", but between "morality" and "profit But between "morality" and "profit", we must put morality first: "Morality and profit are not yet so important. Morality and profit are like the head and tail. Morality is also appropriate. The gentleman sees that this thing is appropriate, but that thing is appropriate as the other, but the ruling of its appropriate and for it, then there is no disadvantage. A gentleman only cares about morality, but not about the next part of profit. The villain only cares about the next profit, not the last morality". The gentleman puts morality first, and as a result, morality can produce profit, so if we follow the path of "morality", we will also get "profit". In Zhuzi's context, this "profit" mostly refers to "public profit". Zhu Zi believes that we should pursue the public interest for the world, to "morality" of the requirements of selfcultivation, to keep the principles of heaven. Therefore, Zhu Xi's so-called "morality" and "profit" is actually unified: "profit" is only to adhere to the "morality" Conversely, in order to obtain the real "profit", that is, "public interest", we should also take morality as the first.

$\mathrm{Zhu} \mathrm{Zi}$ has said: "Morality is a thing that has a bounded division and a broken system, and is suspected of being discordant. However, so that each thing gets its share, do not encroach on each other, is so for and also." If we act with a "righteous mind", then all the people in heaven and earth will naturally have their own share and achieve the harmony of heaven and earth. When heaven and earth are in harmony, everything in the world is in natural harmony, which is a kind of "benefit" for everyone; if we act with a "benefit mind", it will give rise to all kinds of disadvantages, not only detrimental to people, but also harmful to them. Therefore, $\mathrm{Zhu} \mathrm{Zi}$ insisted not on not talking about "profit", but less about "private profit", and insisted on starting from a "righteous heart", so as to obtain the real "profit" in the end. "This is a response to Mencius' view of morality and profit. This is a kind of inheritance and development of Mencius' view of morality and profit, and its logic is still the same: by practicing "morality", both morality and profit will naturally be unified. 


\section{THIS PAPER TAKES A MORALITY AND PROFIT-BASED VIEW}

In the previous article, we learned from analyzing the traditional Chinese view of morality and profit that both sides, whether utilitarianism or moralism, have a tendency to unify morality and profit from their specific positions. We believe that it is inappropriate to favor either utilitarianism or moralism, and that morality and interests should be unified. This "unification of morality and profit" is different from the traditional Chinese view of morality and profit in two ways: First, we give "morality" a clearer and more appropriate connotation for modern society - "love for others" and "love for others". First, we give "morality" a clearer and more appropriate connotation for modern society - "loving people" - and advocate that morality and profit should be unified from the standpoint of "loving people"; second, we believe that "profit" includes more than just public interest. While the common good of the group is important, the interests of the individual should be protected as well. We will elaborate on these two points in this section.

\subsection{Definition of "Goodness"}

We believe that the importance of "goodness" should be emphasized. What is "goodness"? In his book, "Human Freedom and the Good", Fung Chee defines it. He suggests that the definition of goodness needs to be distinguished from two perspectives: goodness in the broad sense refers more to people's daily life and can be equated with "goodness. What is "good"? For a person, satisfying his or her own preferences or needs is good. This preference and pursuit is the benefit. Of course, "good" does not mean that people can pursue their own interests without limit, but it requires people to pursue their interests reasonably, which is good in a broad sense; good in a narrow sense refers specifically to the moral level, referring to good moral behavior. Thus, we believe that the discussion of goodness in either the narrow or the broad sense must involve the question of the debate between morality and profit. Therefore, the study of the debate between morality and profit is essential.

\subsection{On the Debate between Morality and Profit}

Our basic position on the relationship between morality and profit is the unity of morality and profit. Since we talk about "morality" and "profit", we must be clear that they are based on human beings. Feng Qi has said that morality and profit are closely related to the relationship between human beings. In fact, the debate of morality and profit is to find an answer to the question of how people deal with each other. The relationship between people needs to be regulated by a kind of norm, that is, a moral code, and people's behavior should follow the moral code, which is exactly what deontology advocates. However, the purpose of establishing a moral code to regulate behavior is to make society harmonious and stable, that is, to maximize the collective interest, which is advocated by utilitarianism. We believe that moralism and utilitarianism should be viewed together, as Fung Chee says: "They both emphasize one side of each. The correct statement should be the unity of the two, and both 'morality' and 'profit' should be regarded as historical categories, and both are said to be relative to certain social relations". Morality and interest should be unified.

At the same time, on the basis of the unity of morality and profit, we advocate the promotion of "morality" and the correction of "profit". How to promote "morality"? By establishing etiquette and law: by using etiquette to promote good behavior of individuals and by using law to restrain evil behavior of individuals. Through manners and laws, we can make our behavior better conform to moral principles; how to correct "profit"? We can maintain the social order by emphasizing "morality" so that both collective and individual interests can be properly satisfied. However, it should be noted that the premise of satisfying interest is that it must conform to the basic requirement of "do unto others as you would have them do unto you" and to moral principles. We need to distinguish between what is desirable and what is not, and this is the correction of "interest".

\section{3. "Love"}

Finally, we believe it is important to emphasize the important role of love in the relationship between morality and profit. In his concept of morality and profit, Feng Qi introduces an important concept - "love". "Love in Feng Qi's case refers to benevolence. He says, "The subject of morality is human beings, and the relationship between human beings is dealt with by moral principles. Feng Che equates this "love" with the principle of humanity as the basis for all moral behavior. This is very reasonable. Of course, moral behavior is not to give up all interests, but to put "benefit for others" above "love for others", i.e., the above-mentioned principle of benevolence and humanity, which is called "Do unto others as you would have them do unto you". In addition, the expression of "love" should be conscious and voluntary. Although people's moral behavior needs to be regulated by interests and laws, it should come from the heart: people should be "moral" for the sake of "morality", and morality is both an end and a means.

\subsection{Promote "Morality" and Correct "Profit"}

In summary, we advocate the unification of morality and profit in our view of morality and profit, while promoting "morality" and correcting "profit". We can see that this is the inheritance and redevelopment of the traditional Chinese view of morality and profit. The traditional Chinese view of morality and profit, whether 
it is moralism or utilitarianism, contains a certain degree of morality and profit, but the ancients often defined the "profit" in morality and profit as public interest and emphasized the collective principle, which is different from our view. The concept of morality and profit should focus on people themselves. Feng Qi once said, "Moral behavior should be in line with the utilitarian interests of certain social groups, and correctly resolve the relationship between collective and individual interests." We should put individuals into the consideration of the debate of morality and profit, and attach importance to the principles of humanity and benevolence, which is a rethinking of the traditional Chinese view of morality and profit.

\section{INSPIRATION FOR CONTEMPORARY SOCIETY}

Through the above explanation, we believe that a unified view of morality and profit based on "love" is exactly the view of morality and profit that is urgently needed in contemporary society. Contemporary Chinese society has been greatly influenced by Western utilitarianism in its view of morality and profit. Western utilitarianism is based on happiness and pleasure, and the problem they try to solve is how to maximize the "good" of the group. Utilitarians believe that happiness should be used as a means to pursue the "good", i.e., the free development of human beings. Their basic logic is: from the quality of individual happiness to the happiness of the whole group (the free development of the human being), and ultimately to happiness and the "good". In this logical chain, it is necessary to create authority figures, to give certain standards of happiness, and to impose sanctions of conscience in order to break through from individual happiness to the happiness of the whole, which can only be ensured by the guilt and pain of violating one's obligations due to education.

The theory of utilitarianism has something in common with the utilitarian side of the traditional Chinese view of morality and profit: both take the common good of the group as the criterion for maintaining social harmony and stability. However, in such a view of morality and profit (especially in Western utilitarianism), we cannot find a place for the individual. Does this mean that we can sacrifice the interests of the few for the happiness of the many? Is this moral? We believe that being influenced by this kind of thinking can bring about extreme spiritual repression and unfreedom for people. This is not only true in the West, but also in China, where people are facing this crisis. Therefore, it is necessary to reconstruct a unified view of morality and profit based on "love".

\section{CONCLUSIONS}

Admittedly, we recognize that "benefitting people" is necessary. However, how to "profit" and how to "benefit" is indeed a great problem. We advocate "benefitting people" on the basis of "loving people", starting from the principles of humanity and love, and taking the development of human nature as the fundamental. From this point of view, it is natural to oppose the principle of maximizing collective interests. As Kant said, human is an end rather than the means, we should not simply ask individuals to compromise with the collective, but should make moral behavior in line with the collective interests of society and at the same time correctly deal with the relationship between collective and individual interests. Such an attitude will enable our society to develop continuously while preserving the morality and warmth among people.

\section{REFERENCES}

[1] Zhao Shouzheng: Guanzi, Nanning: Guangxi People's Publishing House, 1982.

[2] Yang Bojun: Mencius (Simplified Chinese Version), Beijing: China Book Bureau, 2008.

[3] Li Jinde: Zhuzi, Beijing: China Book Bureau, 1986.

[4] Feng Qi: Human Freedom and True Beauty, Shanghai: East China Normal University Press, 1996.

[5] Xu Bin. The Discernment of Morality and Profit: The Transmutation of the Traditional View of Morality and Profit and Its Implications--From Zhu $\mathrm{Xi}$ to Kang Youwei, Journal of Wuyi University,2018, pp. 1-5. (In Chinese)

[6] Jia Jinhua, Huang Chenxi. Obligations and Rights: From Ritual to Classical Confucianism's View of Morality and its Modern Implications. Confucius Studies, 2019, pp. 28-36. (In Chinese) 